\title{
Lao body part terms
}

\author{
N.J. Enfield \\ Max Planck Institute for Psycholinguistics, Postbus 310, 6500 AH Nijmegen, The Netherlands
}

\begin{abstract}
This article presents a description of nominal expressions for parts of the human body conventionalised in Lao, a Southwestern Tai language spoken in Laos, Northeast Thailand, and Northeast Cambodia. An inventory of around 170 Lao expressions is listed, with commentary where some notability is determined, usually based on explicit comparison to the metalanguage, English. Notes on aspects of the grammatical and semantic structure of the set of body part terms are provided, including a discussion of semantic relations pertaining among members of the set of body part terms. I conclude that the semantic relations which pertain between terms for different parts of the body not only include part/whole relations, but also relations of location, connectedness, and general association. Calling the whole system a 'partonomy' attributes greater centrality to the part/whole relation than is warranted.

(C) 2005 Elsevier Ltd. All rights reserved.
\end{abstract}

Keywords: Lao; Tai; Body part terms; Partonomy; Meronymy; Semantic fields

\section{Parts of the body-the Lao inventory}

Lao body part terms are in the class of Nouns, according to morphosyntactic criteria. They appear as direct complements of verbs, occur in numeral classifier constructions, and are not freely combined with markers of aspect and/or modality (Enfield, 2004a,b). This section discusses the inventory of Lao body part terms. Some grammatical phenomena specific to expressions involving body parts are discussed in Section 2. Data were collected during field trips to Laos between 2001 and 2004 by elicitation using methods

E-mail address: nick.enfield@mpi.nl 
Table 1

Lao terms for the face and its parts

\begin{tabular}{|c|c|c|}
\hline Lao term & Translation & Comment \\
\hline \multicolumn{3}{|l|}{ Simplex } \\
\hline naa5 & 'face' & \\
\hline $\operatorname{taa} 3$ & 'eye' & \\
\hline paak5 & 'mouth' & \\
\hline dang3 & 'nose' & \\
\hline kè̀m4 & 'cheek' & \\
\hline khiw4 & 'eyebrow' & \\
\hline sop2 & 'lip' & \\
\hline khaang2 & 'chin, jaw' & \\
\hline nuat5 & 'facial hair' & \\
\hline kamap2 & 'temple' & \\
\hline \multicolumn{3}{|l|}{ Complex } \\
\hline khon3 taa3 & 'eyelash' & lit. 'eye body.hair' \\
\hline naa5 phaak5 & 'forehead' & lit. 'forehead face' \\
\hline nuaj1 taa3 & 'eyeball' & lit. 'eye ball' \\
\hline nang3 taa3 & 'eyelid' and 'lower eyelid' & lit. 'eye hide' \\
\hline hiim2 taa3 & edge of nang3 taa3 'eye hide' & lit. 'eye rim' \\
\hline taa3 dam3 & 'pupil-and-iris' & lit. 'black eye' \\
\hline taa3 khaaw3 & 'white of the eye' & lit. 'white eye' \\
\hline huu2 dang3 & 'nostril' & lit. 'nose hole' \\
\hline piik5 dang3 & 'nostril flange' & lit. 'nose wing' \\
\hline kêêng3 dang3 & 'area between nose and upper lip, where moustache grows' & $\begin{array}{l}\text { lit. 'nose kêêng } 3 \\
\text { (i.e. kêeng } 3 \text { of the nose)' }\end{array}$ \\
\hline
\end{tabular}

described in the 'Elicitation guide on parts of the body' (Enfield, this volume), as well as by notes and observations in field work in Laos since 1990.

An expression is deemed to refer to a part of the body if native speakers report that it fits felicitously into the following frame: ${ }^{1}$

pên3 suan1 nùngl khòng3 haangl-kaaj3
is part one of
is a part of the body'.

The inventory of terms is presented in the following four sub-sections, covering (1) the face and its parts, (2) external parts of the body, (3) internal parts of the body, and (4) other terms associated with the body. Terms are distinguished as to whether they are sIMPLEX (monomorphemic) or COMPLEX (formally polymorphemic).

\subsection{The face and its parts}

Table 1 lists Lao terms for the face and its parts.

Most of the 10 simplex terms, including one for the face itself, do not show obvious differences in meaning to English, ${ }^{2}$ but there are two things to note. First, khaang2 has no

\footnotetext{
${ }^{1}$ See Appendix for key to orthographic convention.

${ }^{2}$ I assume the reader's familiarity with the English inventory, but will try to be explicit about my judgment of the English terms' extensional range where relevant, and where possible.
} 
English equivalent. It refers to the whole lower section of jaw from below one ear to the point of the chin and along to below the other ear. Its extension goes beyond that of English chin (whose lateral extension is not wider than the mouth), but the term does not denote the idea of 'jaw' as a bone. This would be referred to using the expression kaduuk5 khaang2 'jaw (bone)', with khaang2 as a modifier of kaduuk5 'bone'. Second, paak5 'mouth', while not obviously different in extension to English mouth, reveals a more external or lips-oriented notion than that encoded in English mouth (cf. McClure, 1975, p. 84; Wierzbicka, 1980, pp. 80-83). This is revealed by occurrence of the term in collocations which would seem strange or at least marked in English, such as paak5 tèek5 (lit. broken mouth) 'split or cracked mouth' and paak5 dèng3 (red mouth) 'mouth red from lipstick' (cf. Wierzbicka, 1996, p. 386 for the same observation re: usta 'mouth' in Polish). These concepts are better expressed in English using lips, not mouth.

Among the 10 complex terms for parts of the face in Table 1, a few have no English equivalent. One is kêeng3 dang3, a noun phrase whose head is kêeng3, a word with no independent meaning outside this context. Its modifier is dang3 'nose'. The part denoted by the whole expression is thus explicitly associated with the nose, the 'kêeng3 of the nose'. But it is not PART OF the nose. Speakers reject the following frame (cf. (1), above):

(2) *kêeng3-dang3 pên3 suan1 nùngl khòong3 dang3
area.between.nose.and.lip be part one of nose
(The "nose kêêng3" is a part of the nose.)

If anything, the relation is one of location. This part is AT or BELOW the nose. ${ }^{3}$ It is not clear, however, that this location relation is encoded in the morphosyntactic structure of the expression. Simple nominal compounds express a broad array of semantic relations. In the case of kêeng3 dang3, the ENCODED relation between the referent and the nose itself is at the least one of ASSOCIATION, but there is no evidence that the nominal compound encodes any further specificity (cf. the range of relations covered in English nominal compounds such as rice pot, spear head, village chief, ax handle, forest clearing). See Section 3, below, for further discussion.

Two complex terms relating to the eye are nang3 taa3 'eye hide' and hiim2 taa3 'eye rim'. There is no evidence that the relations ['eye':'eye hide'] and ['eye':'eye rim'] are anything more specific than Association. The former refers to the referent of English eyelid as well as to its counterpart below the iris (i.e. the 'lower eyelid'). The latter refers to the rim of nang 3 taa3, where it gives way to the visible part of the eyeball (i.e. the upper and lower parts along which the eyelashes grow, and on which mascara is typically applied). Again, with these two terms, it cannot be determined whether the relation between the head and the modifying element is one of 'part' or 'possession' or other. Speakers reject or are uncomfortable with the following:
(3) ?nang3 taa3/hiim2 taa3 pên3 suan1 nùng1 khòòng3 taa3 hide eye/rim eye be part one of eye (The 'eye hide'/'eye rim' is a part of the eye.)

\footnotetext{
${ }^{3}$ For some speakers, the kêeng 3 dang 3 is above or at the top of the nose, just at or below the point between the eyebrows.
} 
A second notable - but hardly surprising - finding in the complex terms in Table 1 is the non-observance of certain distinctions familiar from English and other languages. Nuat5 'facial hair' encodes no distinction between 'moustache' and 'beard'. A second is the lack of distinction between 'pupil' and 'iris'. A single distinction is made between visible parts of the eyeball, that between taa3 dam3 the 'black eye' and taa3 khaaw3 the 'white eye'. Lao speakers have dark brown irises, meaning that perceptually there is a relatively subtle distinction between pupil and iris. Morphosyntactically, these expressions are interesting, since they are headed by taa3 'eye', although the whole expression does not refer to 'an eye' (just as in English a forearm is not an arm, and a lower leg is not a leg; see Sections 2 and 3 for further discussion).

An additional domain of interest in cross-linguistic data on conventions in categorization of the face and its parts concerns the vocabulary of facial expressions (usually associated with emotion), as well as conventional descriptions of faces which do not denote parts but otherwise do describe faces (e.g. for recognition of individuals). An example of the latter is sop2 bòø hum4 khèew5 (lit. 'lips not cover teeth'), which can be translated as 'Her lips don't cover her teeth'. The same situation is described in English as She has buck teeth. Another collocation is kè̀m4 bòòngl (lit. 'pierced cheek') for 'dimple'. These reveal different construals to English of the same set of phenomena, where the differences concern the feature of the designatum PROFILED by the expression (cf. Langacker, 1987; Chafe, 2000). Consider khèè 5 haangl 'tooth spaced.apart', the conventional way of referring to having a gap between one's teeth. Lao convention foregrounds the TEETH and their distance from each other, while the convention of English is to foreground the GAP between them.

I have elsewhere described Lao conventions for talking about facial expressions of emotion (Enfield, 2001). Examples include naa5 buut5 (lit. 'rotten face'; associated with negative emotional state), hêt1 khiw4 cò̀t5 kan3 (lit. 'make eyebrows park together'; associated with thinking, puzzlement), naa5 mên3 (lit. 'smelly face', associated with disgust), and taa3 tiil (lit. 'eyes held open', associated with surprise, amazement; see Enfield, 2001, for discussion and further examples). While these expressions go beyond segmentation of the PARTS of the face, they are nevertheless conventional resources for talk about bodily phenomena (in this case, visually perceptible phenomena). They also point to an important component of the meaning of naa5 'face'-i.e. that we can learn from it about others' inner states.

\subsection{External parts}

Table 2 lists Lao terms for external parts of the body.

Three terms in Table 2 may be translated in different contexts using the English word body. Of these, only haangl kaaj3 refers generally to the human body, the highest node of the body partonomy. That is, only haangl kaaj3 'body' may serve as the whole for which the terms discussed in this article are said to be parts (by the frame in (1), above). Both morphological components of haangl kaaj3 appear in other contexts - e.g. khoong2 haang1 'structure' (where khoong2 refers to a 'frame'), kaaj3-ña-sin3 'gymnastics' (where $\sin 3$ means 'art'), but neither normally occurs on its own.

Too3 is close to English body in the sense of 'trunk'; central part of the body, not including limbs and head' (as in There were cuts on his arms and legs, but none on his body). It is 
Table 2

Lao terms for external parts of the body

\begin{tabular}{|c|c|c|}
\hline Lao term & Translation & Comment \\
\hline \multicolumn{3}{|l|}{ Simplex } \\
\hline too3 & 'body' & 'trunk' \\
\hline hunl & 'body/figure' & \\
\hline khèèn3 & 'arm' & \\
\hline kaam4 & 'muscle, bicep/upper arm' & \\
\hline khaa3 & 'leg' & \\
\hline mù̀̀2 & 'hand' & \\
\hline $\operatorname{tiin} 3$ & 'foot' & \\
\hline niw4 & 'digit (finger or toe)' & \\
\hline lêp1 & 'claw' & 'nail (of finger or toe)' \\
\hline khawl & 'knee' & \\
\hline khèèng1 & 'lower leg' & segment of leg from knee to ankle \\
\hline sò̀k5 & 'elbow' & cf. synonym khèèn 3 sò̀k5 \\
\hline hua3 & 'head' & \\
\hline phom3 & 'hair of the head' & \\
\hline kamòòm1 & 'crown of head' & part that is soft in babies \\
\hline cò̀m3 & 'peak' & $\begin{array}{l}\text { area at crown of head, } \\
\text { where hair follicles spiral }\end{array}$ \\
\hline huиз & 'ear' & \\
\hline ngòòn1 & 'nape' & \\
\hline khò̀2 & 'neck, throat' & \\
\hline khiing2 & 'torso' & \\
\hline khaang5 & 'side' & \\
\hline lang3 & 'back' & \\
\hline baal & 'shoulder' & $\begin{array}{l}\text { horizontal area from neck to } \\
\text { shoulder joint; = baal lajl }\end{array}$ \\
\hline qèèw3 & 'waist, lower back' & \\
\hline qek2 & 'upper chest' & \\
\hline nom2 & 'breast' & \\
\hline thòòng4 & 'belly' & \\
\hline kатоот2 & 'area above pubis' & \\
\hline kon4 & 'arse' & \\
\hline ham3 & 'testicles' & \\
\hline khooj2 & 'penis' & \\
\hline hii3 & 'vagina' & \\
\hline tèèt 5 & 'clitoris' & \\
\hline sabù̀u 3 & 'belly button' & \\
\hline khon3 & 'body hair' & \\
\hline phiw3 & 'skin' & \\
\hline nang3 & 'hide' & \\
\hline qên3 & 'sinews, visible/raised blood vessels' & \\
\hline \multicolumn{3}{|l|}{ Complex } \\
\hline haang1 kaaj3 & 'body’ & lit. 'body frame' \\
\hline khiis hè̀4 & 'underarm, armpit' & lit. 'hèè shit' \\
\hline naa5 thò̀ng4 & 'centre of belly at front' & lit. 'belly face' \\
\hline thò̀ng4 nò̀j4 & 'lower area of belly at front' & lit. 'small belly' \\
\hline hua3 khawl & 'knee cap' & lit. 'knee head' \\
\hline khaa3 phapl & 'back of knee' & lit. 'fold leg' \\
\hline khaa 3 tooj4 & 'thigh' & lit. 'thigh leg' \\
\hline kok2 khaa3 & 'thigh (joint)' & lit. 'leg base' \\
\hline ngaw5 khaa3 & 'upper thigh' & lit. 'leg branching root' \\
\hline
\end{tabular}


Table 2 (continued)

\begin{tabular}{|c|c|c|}
\hline Lao term & Translation & Comment \\
\hline kok2 khèen3 & 'shoulder (joint)' & lit. 'arm base' \\
\hline ngaw5 khèen3 & 'shoulder (top of arm), deltoids' & lit. 'arm branching root' \\
\hline san3 lang3 & 'spine, muscles flanking spine' & lit. 'back ridge' \\
\hline hò̀̀ng1 lang3 & 'depression running down alongside spine' & lit. 'back channel' \\
\hline hòòng1 qek2 & 'depression running down centre of chest' & lit. 'chest channel' \\
\hline lò̀t5 khò̀2 & 'oesophagus, Adam's apple' & lit. 'throat tube' \\
\hline calò̀k4 khò̀2 & $\begin{array}{l}\text { 'small depression at base of } \\
\text { oesophagus and above sternum' }\end{array}$ & lit. 'throat calò̀k5' \\
\hline hua3 nom2 & 'nipple' & lit. 'breast head' \\
\hline baal laj1 & 'horizontal area from neck to shoulder joint' & lit. 'shoulder' \\
\hline naa5 khèèng1 & 'shin’ & lit. 'lower leg face' \\
\hline biil khèèngl & 'calf' & lit. 'lower leg biil' \\
\hline son 5 tiin 3 & 'heel' & lit. 'foot stub' \\
\hline son5 nò̀ng1 & 'heel' & lit. 'nòòngl stub' \\
\hline tum1 mòòng4 & 'ankle' & morphology unclear \\
\hline khòo5 khaa3 & 'ankle joint' & lit. 'leg joint' \\
\hline lêp1 mùù2 & 'fingernail' & lit. 'hand claw' \\
\hline lêp1 tiin3 & 'toenail' & lit. 'foot claw' \\
\hline khèen3 sòok5 & 'elbow' & lit. 'elbow arm' \\
\hline niw4 kòoj44 & 'little finger/toe' & lit. 'kòoj4 digit' \\
\hline niw4 naang2 & 'ring finger/toe' & lit. 'naang2 digit' \\
\hline niw4 kaang3 & 'middle finger/toe' & lit. 'middle digit' \\
\hline niw4 sii4 & 'index finger/second toe' & lit. 'pointing digit' \\
\hline niw4 poo4 & 'thumb/big toe' & lit. 'poo4 digit' \\
\hline poo4 mùù2 & 'thumb' & lit. 'hand poo4' \\
\hline poo4 tiin 3 & 'big toe' & lit. 'foot poo4' \\
\hline lang3 mùù 2 & 'back of the hand' & lit. 'hand back' \\
\hline san 3 mùù2 & $\begin{array}{l}\text { 'outside edge of hand, from } \\
\text { base of pinkie to wrist' }\end{array}$ & lit. 'hand ridge' \\
\hline faa3 mùù2 & 'palm' & lit. 'hand lid' \\
\hline kok2 lêp1 & 'nail root' & lit. 'nail base' \\
\hline paaj3 lêp1 & 'nail tip' & lit. 'nail tip' \\
\hline khòo5 mùù2 & 'wrist' & lit. 'hand joint' \\
\hline khò̀5 niiw4 mùù2 & 'knuckle' & lit. 'hand digit joint' \\
\hline huu2 kon4 & 'anus’ & lit. 'arse hole' \\
\hline kon4 khii5 & 'anus' & lit. 'shit(ting) arse' \\
\hline nang3 ham3 & 'scrotum' & lit. 'testicle hide' \\
\hline nuaj1 ham3 & 'testicle' & lit. 'testicle unit' \\
\hline paaj3 khooj2 & 'tip of penis' & lit. 'penis tip' \\
\hline hua3 khooj2 & 'head of penis' & lit. 'penis head' \\
\hline kok2 khooj2 & 'base of penis' & lit. 'penis base' \\
\hline nang3 khooj2 & 'foreskin' & lit. 'penis hide' \\
\hline hiim2 hii3 & 'labia' & lit. 'vagina rim' \\
\hline huu2 hii3 & 'birth canal' & lit. 'vagina hole' \\
\hline qiil moq2 & 'vagina (diminutive connotation)' & $\begin{array}{l}\text { moql plus female } \\
\text { non-respect prefix qiil- }\end{array}$ \\
\hline
\end{tabular}

also used in certain contexts to refer to the overall body as having a certain size and shape. ${ }^{4}$ Thus:

\footnotetext{
${ }^{4}$ The term $t o o 3$ is used with reference to animal bodies, and is also one of the most common nominal classifiers, used prototypically for counting animals (e.g. muи 3 saam3 too3 [pig three body] 'three pigs'). In the context of reference tracking and other types of nominal reference, too3 has generalised into a 'residual' classifier (Enfield, 2004a).
} 
(4) phua3 man2 too3 ñaj1

husband 3SG body big

'Her husband (has a) big body (i.e. is of big build)'.

Speakers reject the use of haangl kaaj3 'body' here.

The third 'body' term in Lao is hunl, best translated as figure. One can describe a person as having a hun1 ñajl 'big body/figure' or hun1 ngaam2 'good figure, nice body'. But one cannot say that the nose or the arm is 'part of the hunl'. The word hunl also means 'puppet, doll, mannequin' in other contexts.

The terms khaa3 'leg', khèen3 'arm', mùù 'hand' and tiin3 'foot' do not appear to be different in meaning to their English equivalents. These are further discussed in Section 3 , below, with reference to the issue of putative partonomic relations among them.

Niw4 'digit' is general with respect to its reference to fingers or toes. When required, a distinction between fingers and toes is made by adding either mùù 'hand' or tiin3 'foot' as a modifier, giving niw4 mùù2 'finger' (lit. 'hand digit') and niw4 tiin3 'toe' (lit. 'foot digit'). Each digit has a name, consisting of niw4 in combination with a modifier. In two cases, the modifier is specific to that expression and does not occur elsewhere (poo4 for thumb/big toe and kòjj4 for pinkie). Another two are descriptive (kaang3 'middle' for middle finger and sii4 'point, stick out' for index finger). The remaining term is niw4 naang2 'ring finger', in which the modifier is naang2, elsewhere meaning 'girl, young woman'. Consultants differ as to whether they attribute any conceptual connection between the ring finger and the idea 'girl, young woman'.

Nails are referred to using lêpl 'claw' (so glossed because it is also used for reference to animal claws). This term is not specific as to whether the nail belongs to a finger or a toe. When a distinction is required, the 'digit' word will not suffice, since it is also general with respect to whether it belongs to a hand versus a foot. As a consequence, the specific terms for nails are lêp1 mùù2 'HAND nail' and lêp1 tiin3 'FOOT nail', not *lêp1 niw4 (mùù2) ((hand) digit nail) (cf. Palmer and Nicodemus, 1985, p. 344).

Lao does not have an equivalent to English shoulder. Lao baal or baal lajl refers to the flattish (i.e. horizontal) region between the base of the neck and the shoulder joint. This part of the body is covertly denoted by a carrying verb bè $k 5$, which refers to carrying something by taking its weight on one's baal; i.e. 'ON one's shoulder'. English shoulder includes this part, but also includes the uppermost part of the arm directly adjoining the torso (McClure, 1975, p. 80). This latter part (i.e. deltoids and shoulder joint) is referred to in Lao as ngaw5 khèen3 'arm branching-base'. English shoulder apparently centres at the joint between arm and torso and covers the area to both sides of this joint (hence the possibility of having a dislocated shoulder), while according to the conventions of Lao, the joint is where the baal (laj1) ends and the ngaw5 khèen3 begins. A 'dislocated shoulder' cannot be described in Lao using baal, and is expressed either as ngaw5 khènn lot1 'arm branching-base dislocate' or simply khèen3 lot1 'arm dislocate'. These kinds of collocational restrictions can provide good evidence for semantic content, demonstrating a significant distinction between English shoulder and Lao baal (despite the latter often being translated as shoulder).

Lao speakers conventionally distinguish, using simplex terms, between five different referents for what in English could be called hair. Two mentioned in the above section on the face and its parts are khiw4 'eyebrow' and nuat5 'facial hair (moustache/beard)'. Three listed in Table 2 are the semantically general term khon3 'body hair' (which also refers 
to fur and feathers), and the semantically specific terms phom3 'head hair' and mòj3 'pubic hair'. The latter is one of the rudest words in the Lao language. Khiw4 'eyebrow' is the only of the Lao terms for hair that allows modification by najl 'big', suggesting that the term refers to a THING made up of hair, while the other terms refer to hair as a MASs.

Tiin3 'foot' is considered rude in certain circumstances and is often avoided. Upon entering a house as a guest in southern Laos, I was once invited to sêt1 khaa3 'wipe (the) legs' on the way in. The context (muddy shoes, doormat at the entrance to the house) clearly indicated that the intended referent was the feet, not the legs. Speakers I later consulted agree that to have referred explicitly to the feet in this case would have sounded bò muanl huu3 'not nice (on the) ears'. Such avoidance is associated with a genuine disdain for the feet, maintained in Lao speakers' cultural practices and beliefs. The feet are considered 'low', especially in contrast to the head, and there is a range of ways in which this is observed in everyday behaviour. For example, there are strict norms against using the feet for practical actions such as moving things or picking things up, pointing with the feet, or 'crossing' (i.e. stepping over) people or objects (especially food and religious or personal items). Feet are among the 'low' things that ideally should be kept in a low position, and especially should not touch or go above people's heads. ${ }^{5}$ I have more than once observed drivers of public transport vehicles apologise in advance to passengers for 'going over their heads' before stepping up onto the roof of the vehicle to attend to baggage. Similar beliefs among Thai speakers are taken to further extremes. When a high-ranking member of the Thai royal family travels across the city of Bangkok, police clear traffic on pedestrian overpasses and bridges en route, to ensure that no person will be physically above the royal personage as he or she travels through. These practices among Thai speakers are accompanied by the presence in Thai of higher register terms for the foot, tháaw for human feet and $f \breve{a} a$ bàat for royal feet (see Juntanamalaga, 1992). Tiin in Thai refers only to animal feet, or dysphemistically to human feet (cf. English hoofs). Many languages supply alternative terms for the same body part, encoding register differences or differences in connotation, often where the 'lower' term is also used for animals. Compare English hands versus paws or mitts, teeth versus fangs, mouth versus snout (cf. cake hole, pie hole, kisser), and of course the many terms for genitalia and their parts. ${ }^{6}$ The two Lao terms for 'heel' differ in level of politeness, indexed by the presence or absence of the morpheme tiin3 'foot'. While the expression son4 tiin3 'foot stub' is considered 'not nice', son4 nò̀ng1where the modified nò̀ngl has no independent meaning - is not impolite. ${ }^{7}$ The term for 'ankle joint' is khòo5 khaa3, literally 'leg joint'. Its equivalent for the arm is khò̀5 mùù2 'HAND joint' (not 'arm joint'). When speakers were asked why the ankle is not called khò 5 tiin3 'foot joint', they replied that it would sound, again, 'not nice', due to presence of the word tiin3 'foot'.

\footnotetext{
5 Another is the $\sin$, the traditional Lao women's skirt. Custom has it that the $\sin$ must be stored in the home as close to the floor as possible.

${ }^{6}$ These terms do not always differ solely in register or connotation, but often encode additional distinctions in referential meaning such as shape, size, state, configuration, or function. Compare titties versus jugs versus fun bags, widdler versus pecker versus rod.

${ }^{7}$ Rude speech in Lao often includes gratuitous reference to the foot e.g. jaal maa2 kuan3 tiin3 kuu3 'Don't bloody disturb me!' (lit. 'Don't come and disturb my foot/feet'.) (Cf. Juntanamalaga, 1992, p. 169, on Thai.) The most offensive threats and insults refer to stepping on or kicking a person, especially a part of their body in the area of the head: jiap5 khò̀2 'step on (your) neck', têq2 khò̀2 'kick (your) neck', têq2 paak5 'kick (your) mouth'. These carry roughly the tone of English (I'll) punch (your) fuckin' head in.
} 
Nang3 'hide' refers to animal hide as well as to human skin in general. The term is regarded as inappropriate in register with respect to human skin where it can be seen as a flat, soft, even expanse, e.g. on the face, torso, or limbs. It is appropriate for flaps of skin or loose skin such as on the eyelids or the scrotum. Phiw3 refers to a flat covering surface of human skin (although nang3 also covers this).

Khò̀2 'neck, throat' is ambiguous, sometimes referring to the neck and sometimes referring to the throat. This is supported by the inability to get a general reading for cêp2 khò̀2 (sore neck/throat), which may mean 'sore neck' (e.g. from sleeping in an odd position) or 'sore throat' (e.g. from smoking).

Further terms of note are khèèngl ('lower leg', the section of the leg analogous to the forearm, from knee to ankle, of which 'shin' and 'calf' are parts), san3 mùì 'hand ridge' (the outside edge of the hand from base of pinkie to wrist), qè̀w3 (waist and lower back), calòok5 khò̀2 (small depression where base of neck/throat meets sternum), and qên3 (a broad category of tough, fibrous stringy tissue, both internal and external to the body, including sinews and gristle as well as visible blood vessels and the penis).

Among complex terms, a number of specifying elements recur. These include ngaw5 'branching base', kok2 'base', paaj3 'tip', san3 'ridge', khòo5 'joint', and hòòngl 'groove, channel'. These terms are not derivationally productive. Thus, there are parts of the body such as the knee and elbow which could conceivably be described by khòo5 'joint', but where conventional terms pre-empt such description. Lao speakers refer to the elbow using sò̀k5 'elbow' and not *khòo5 khèen3 (arm joint). But, unlike in English, there is no basic term for 'wrist', and this body part is referred to with khò̀ 5 mùù 'hand joint'. The overall meanings of these polymorphemic expressions are lexically specified, not computed from the meaning of the parts (as in the case of, say, left arm). The term khòo5 mùù 'hand joint' refers to the WRIST, and not just any joint associated with the hand (e.g. 'knuckle'). Similarly, while one could imagine a number of candidates for referent of 'ridge of the back' and 'ridge of the hand', the ones actually picked out by the expressions san3 lang3 'back ridge' and san3 mùù 'hand ridge' are lexically specified.

\subsection{Internal parts}

Table 3 lists Lao terms for internal parts of the body.

If conceptual categories are built from experience, as I suppose they are, people's concepts of internal parts of the body must be qualitatively different to those of their visible parts. People seldom if ever see or handle the internal parts of people's bodies. Many people of course do regularly see and handle internal body parts of other animals. But what is the average person's evidence that an animal's insides are homologous to those of a human? I suggest that the linguistic conventions themselves play a role. English speakers do not doubt, I think, that a chicken's kidneys are in some sense the same as a person's kidneys. Lao speakers, however, balk at this suggestion. They have distinct terms: taj3 for chickens and other animals, maak5 khaj1 lang3 (literally 'back egg fruit') for people. Lao speakers I have consulted disagree as to whether people have taj3. Those who think they do are not quite sure. English speakers apparently assume that chickens and humans share this crucial body part. It may be that, in the absence of evidence to the contrary, common labelling with the word kidney is evidence in favour of this assumption.

It is unclear whether the term khuan3 denotes a part of the body. Only some speakers are willing to accept it in the frame (1). A person has multiple khuan3, which are located at 
Table 3

Lao terms for internal parts of the body

\begin{tabular}{|c|c|c|}
\hline Lao term & Translation & Comment \\
\hline $\begin{array}{l}\text { Simplex } \\
\text { saj5 } \\
\text { tap2 } \\
\text { taj3 } \\
\text { pò̀t5 } \\
\text { samòòng3 } \\
\text { ngùak4 } \\
\text { liin4 } \\
\text { khè̀w5 } \\
\text { kaduuk5 } \\
\text { phung2 } \\
\text { kaphòq1 } \\
\text { maam4 } \\
\text { khuan3 } \\
\text { siin4 } \\
\text { nò̀ng4 }\end{array}$ & $\begin{array}{l}\text { 'guts' } \\
\text { 'liver' } \\
\text { 'kidney' } \\
\text { 'lung' } \\
\text { 'brain' } \\
\text { 'palate' } \\
\text { 'tongue' } \\
\text { 'tooth' } \\
\text { 'bone' } \\
\text { 'stomach' } \\
\text { 'stomach' } \\
\text { 'spleen' } \\
\text { 'spirit' } \\
\text { 'flesh' } \\
\text { 'placenta' }\end{array}$ & lit. 'younger sibling' \\
\hline $\begin{array}{l}\text { Complex } \\
\text { hua3 caj3 } \\
\text { saj5 ting1 } \\
\text { lam2 saj5 } \\
\text { phok1 ñiaw1 } \\
\text { thong3 bii3 } \\
\text { sòong1 khòot4 } \\
\text { mot1 luuk4 } \\
\text { saaj3 hèè1 } \\
\text { piik5 mot1 luuk4 } \\
\text { paaj3 liin4 } \\
\text { kok2 liin4 } \\
\text { fên2 khèèw5 } \\
\text { khèèw5 nam4 nom2 } \\
\text { khèè } 5 \text { saaw2 } \\
\text { khèèw5 kok2 } \\
\text { thò̀1 lùat4 } \\
\text { kalook5 hua3 } \\
\text { lùak5 kaj1 } \\
\text { sên5 pasaat5 } \\
\text { maak5 khaj1 lang3 } \\
\text { khaj3 man2 }\end{array}$ & $\begin{array}{l}\text { 'heart' } \\
\text { 'appendix' } \\
\text { 'intestines' } \\
\text { 'bladder' } \\
\text { 'gall' } \\
\text { 'birth canal' } \\
\text { 'uterus' } \\
\text { 'umbilical cord' } \\
\text { 'fallopian tube' } \\
\text { 'tip of the tongue' } \\
\text { 'root of the tongue' } \\
\text { 'gum' } \\
\text { 'milk tooth' } \\
\text { 'wisdom tooth' } \\
\text { 'molar' } \\
\text { 'blood vessel' } \\
\text { 'skull' } \\
\text { 'uvula' } \\
\text { 'nerve' } \\
\text { 'kidney' } \\
\text { 'fat' }\end{array}$ & $\begin{array}{l}\text { lit. 'heart head' } \\
\text { lit. 'appendix gut' } \\
\text { lit. 'gut tube' } \\
\text { lit. 'piss bladder' } \\
\text { lit. 'bile bag' } \\
\text { lit. 'birth canal' } \\
\text { lit. 'child uterus' } \\
\text { lit. 'procession string', } \\
\text { 'lit. 'child uterus wing' } \\
\text { lit. 'tongue tip' } \\
\text { lit. 'tongue base' } \\
\text { lit. 'tooth gum' } \\
\text { lit. 'milk tooth' } \\
\text { lit. '20 tooth' } \\
\text { lit. 'base tooth', } \\
\text { lit. 'blood pipe' } \\
\text { lit. 'head skull' } \\
\text { lit. 'chicken uvula' } \\
\text { lit. 'nerve fiber' } \\
\text { lit. 'back egg fruit' } \\
\text { synonym compound (both words mean 'fat') }\end{array}$ \\
\hline
\end{tabular}

various different points on the body, the most salient one (and the default reading of the term) being centred in the còm 3, the area at the top of the head where the hair follicles curl. The khuan 3 is partly independent of the physical person. People believe that it can get lost or left behind in certain situations, causing physical and psychological problems. The khuan 3 of very young children is especially vulnerable.

The word for the physical heart is hua 3 caj3, where hua 3 means 'head' and caj3 is a more general term meaning 'core' or 'centre'. Caj3 may sometimes be used alone to refer to the heart as an organ, but it is more often encountered in expressions referring to the 'heart' as a locus of emotion and other inner experience (Matisoff, 1986; Enfield, 2002). The term caj3 'heart' is involved in hundreds of expressions for emotion and personal 
attributes. These are morphosyntactically of two forms, with caj3 in either initial, or final position. Expressions with caj3 in initial position describe inherent or enduring character traits, for example caj3 dii3 (lit. heart good) 'nice, considerate, generous', caj3 dam3 (lit. heart black) 'evil, wicked, mean', caj3 kuang4 (lit. heart broad) 'generous'. Expressions with caj3 in final position describe temporary emotional states, for example dii3 caj3 (lit. good heart) 'happy', tok2 caj3 (lit. fall heart) 'surprised, shocked', sia3 caj3 (lit. lost heart) 'sad, regretful' (cf. Diller and Juntanamalaga, 1990 on Thai).

\subsection{Other terms}

Table 4 lists terms which are associated with the body but which are problematic or unacceptable in the ' $\mathrm{X}$ is a part of the body' frame ((1), above). These are bodily products such as blood, non-necessary features like birthmarks and scars, and notions such as fist

Table 4

Further terms: not 'parts of' the body, but found in or on it

\begin{tabular}{|c|c|c|}
\hline Lao term & Translation & Comment \\
\hline \multicolumn{3}{|l|}{ Simplex } \\
\hline khii5 & 'shit' & \\
\hline ñiawl & 'piss' & \\
\hline lùat4 & 'blood' & \\
\hline bii3 & 'bile' & \\
\hline nò̀̀ng3 & 'pus' & \\
\hline hùal & 'sweat' & \\
\hline lang2khèè2 & 'dandruff' & \\
\hline pè̀w4 & 'scar' & \\
\hline baat 5 & 'cut, wound' & \\
\hline fii3 & 'boil' & \\
\hline siw3 & 'pimple' & \\
\hline tuml & 'lump, skin eruption' & \\
\hline mùkl & 'freckle' & lit. 'ink' \\
\hline paan3 & 'birthmark' & \\
\hline tak2 & 'lap' & \\
\hline kampan4 & 'fist' & \\
\hline \multicolumn{3}{|l|}{ Complex } \\
\hline khii5 dang3 & 'crusty snot' & lit. ' nose $_{1}$ shit' \\
\hline khii5 muuk4 & 'runny snot' & lit. ' $\operatorname{mose}_{2}$ shit' \\
\hline khii5 huиз & 'ear wax' & lit. 'ear shit' \\
\hline khii5 taa3 & 'sleep' & lit. 'eye shit' \\
\hline khii5 khaj2 & 'body grime' & lit. 'moss shit' \\
\hline khii5 mè̀ng2 van2 & 'freckle' & lit. 'fly shit' \\
\hline khii5 katòòt5 & 'wart' & lit. 'wart shit' \\
\hline khii5 katheq1 & 'mucus' & lit. 'mucus shit' \\
\hline nam4 taa3 & 'tears' & lit. 'eye water' \\
\hline nam4 bèèn4 & 'semen' & lit. 'semen water' \\
\hline nam4 nom 2 & 'milk' & lit. 'breast water' \\
\hline nam4 laaj2 & 'saliva' & lit. 'saliva water' \\
\hline khon3 dang3 & 'nostril hair' & lit. 'nose body.hair' \\
\hline khon3 huиз & 'ear hair' & lit. 'ear body.hair' \\
\hline song 2 phom 3 & 'hairdo' & lit. 'head.hair disposition' \\
\hline
\end{tabular}


and lap which exist only by virtue of adopting a certain posture (McClure, 1975, p. 85). While they are not PARTS OF the body, they are regarded by speakers as IN, ON, or COMING OUT OF the body.

Khii5 'shit' is widely used in lexical derivation in Lao (Enfield, 2004a). Some terms idiosyncratically include this morpheme where it has no clear semantic contribution (e.g. khii5 hè 4 'armpit'; hè 4 has no independent meaning). Other terms seem to be metaphoric, such as khii5 mèeng2 van2 (lit. 'fly shit') for 'freckle'. One large class of words in Lao featuring khii5 'shit' as a class term prefix consists of terms denoting waste products such as khii5 lùajl 'sawdust' or khii5 ñùal 'garbage'. Among terms of this kind relating to the body, some are relatively transparent in meaning, such as khii5 huu3 'ear shit' (ear wax) and khii5 taa3 'eye shit' (sleep). Others are not. Khii5 khaj2 'moss shit', for example, has no equivalent in English apart from the technical term sebum. This 'moss of the body' refers to the oily secretion of the sebaceous glands that acts as a lubricant for the skin and hair.

Lao distinguishes two types of snot, both of which mean literally 'nose shit'. Khii5 dang3 'nose shit (crusty)' refers to crusty snot which can be picked or scraped off (i.e. as complement of the verb kèq2 'pick off, scrape'). This term features the element dang3, the everyday word for 'nose'. Khii5 muuk5 'nose shit (runny)' features muuk5, a word which does not appear independently in Lao (but is cognate with Thai camùuk, the regular word for 'nose'). Unlike khii5 dang3 'nose shit (crusty)', this term can appear as the complement of sangl 'blow (the nose)'. This is another example of different perspectives being taken in Lao and English conventions for description of identical phenomena. English speakers blow and pick their NOSES, and do not blow or pick their SNOT. A Lao speaker, on the other hand, will sangl khii5 muuk4 'blow runny snot' and/or kèq2 khii5 dang3 'pick crusty snot', rather than ?sangl dang3 (blow nose) or ?kèq2 dang3 (pick nose). (Kèq2 dang3 'pick nose' is fine with the interpretation 'pick at the outer surface of the nose'.)

Nam4 'water, liquid' is highly productive in derivation in Lao, and there are several terms among the liquid products of the body which feature this element. There are four such terms in Table 4 (denoting 'tears', 'semen', 'milk', and 'saliva'). Most of the basic liquid-denoting terms (those denoting 'piss', 'bile', 'pus' and 'sweat') can optionally appear with nam4 added as a 'class term' prefix (Enfield, 2004a). The only exception is luat4 'blood'.

An intriguing category consists of those terms which denote parts of the body IN SPECIFIC CONFIGURATIONS (McClure, 1975, p. 85). Examples from English include the nouns fist, lap, and smile. Lao has tak2 'lap', which like its English equivalent is often described in elicitation as a place where a child can sit. Kampan4 'fist' is a notion both physically and functionally determined, i.e. not just a hand in a certain configuration, but in that configuration for a certain purpose (typically hitting; this configurational body part is incorporated into the semantics of the English verb punch). Terms for gestures such as pointing or waving, and for facial expressions such as smiling or frowning in Lao (Enfield, 2001) are verbal expressions (e.g. ñim4 'smile', sii4 (mùù) 'point (the hand)', ngek1 hua3 'toss (the head)'), and are not further discussed here.

Related to the issue of body part configuration is that of the human body as a standard of measure. A number of traditional Lao measure terms refer to parts of the body. Two terms - khùù 4 'hand span' and vaa2 'arm span'-make reference to parts of the body in specific configurations (open hand and outstretched arms, respectively). Other measure terms involving body parts include niw4 'inch' (lit. 'finger') and sòok5 'cubit' (lit. 'elbow'). 
This concludes our sketch of the inventory of terms for parts of the body in Lao. ${ }^{8}$ The discussion has been restricted to 'literal' meanings of the body part terms. Many terms considered to literally or prototypically refer to parts of the human body in Lao are also used for reference to (parts of) inanimate objects and other things. Examples include hua3 'head' (e.g. root vegetables, of a bed, of the evening), kon4 'arse' (e.g. base of a pot, boot of a car), tiin3 'foot' (e.g. of a mountain), huu3 'ear' (e.g. of a cup, bucket, pot, bag), khaa3 'leg' (e.g. of a table, tripod), taa3 'eye' (e.g. of a net), paak5 'mouth' (e.g. of a bottle, a river), thòong4 'belly' (e.g. of the sky), khèèw5 'tooth' (e.g. of a comb, a cog), naa5 'face' (e.g. of a table, of a body of water), lang3 'back' (e.g. top of a cupboard, roof of a house), haang3 'tail' (e.g. of a river island). Some basic body part terms are not conventionally applied to (parts of) inanimates (e.g. mùù 'hand', khèen3 'arm'). Body part terms are sometimes used for reference to areas of spatial extension (e.g. naa5 'face'/'in front', lang3 'back'/'behind', khaang5 '(to the) side'). Another area of reference to the body excluded from consideration in this paper is the COVERT categorization of the body and its parts. Verbs of donning and wearing may make reference to some categorization of parts of the body (Schaefer, 1985; cf. Lao nungl 'put on/wear pants or shirt or jacket or any other clothing items classified by too3 "body", versus saj1 "put on/wear anything else on feet or head, or something less enclosing on the body, such as jewellery). Finally, many verbs of action implicate or entail the involvement of various parts of the body (e.g. têq2 'kick (with the foot)', son2 'butt (with the head)', mùùn2 'open the eyes', mim2 'compress the lips', ngek1 hua3 'toss (the) head', sii4 mùu 'point (with the) hand/finger', kom4 'bow, duck'). Exploration of these issues is reserved for another context.

We now turn to some observations concerning the grammatical behaviour of body part terms.

\section{Grammatical observations}

\subsection{Body parts and classifiers}

Lao features a grammatical system of nominal classification, which shows properties of a typical 'numeral classifier' system (Aikhenvald, 2000; Grinevald, 2000), with further extended functions (Enfield, 2004a). As nouns, body part terms are assigned classifiers for counting and for various pronominal references. For some body part terms, the appropriate classifier is nuaj1 'three-dimensional unit' (typically used for fruits and various other 'assembled' and transportable items like tables or computers), used with reference to eyes, testicles, kidneys, and the heart. 'Two eyes' may thus be expressed as taa3 sòong3 nuaj1 (lit. 'eye two unit'). For body part terms which refer to symmetrical parts, one on each side of the body - e.g. terms denoting arms, legs, eyes, cheeks, or ears - bùang4 'side' may be used. An alternative expression of 'two eyes' is thus taa3 sò̀ng3 bùang4 (lit. 'eye two side'). It is also possible to use 'repeater classifiers', as in yet another rendering of 'two eyes' taa3 sòòng3 taa3 (lit. 'eye two eye') 'two eyes'.

\footnotetext{
${ }^{8}$ Many if not most Lao terms for human body parts are also used with reference to animals. Some terms show equivalences not observed by English convention (e.g. sop2 'lips' for reference to a bird's beak). Animal-specific terms include kêt2 'scales (of a fish)', ngeep4 'gills (of a fish)', haang3 'tail', and piik5 'wing'.
} 


\subsection{Structure of compounds}

The majority of noun-noun (N1-N2) compounds among the complex body part terms feature the 'larger whole' as modifier (N2), and the other component (whose referent is part of or connected to or located at or otherwise associated with the whole) as head, i.e. N1. Examples involving dang3 'nose' in N2 position (i.e. modifier) are illustrated here:

(5) a. kêeng3 dang3 'area between nose and upper lip' (BELOW/ADJACENT To the nose)

b. piik5 dang3 'nose wing' (PART OF the nose)

c. khii5 dang3 'nose shit' (FOUND/LOCATED IN the nose)

Two compounds are symmetrical: haangl kaaj3 'body' and khaj3 man2 'fat'. The two elements each refer to the whole, and no relation of association is relevant.

A number of complex body part terms display an exceptional grammatical structure, reversing the order of elements shown in (5). Whereas normally the whole entity of which the referent is associated is denoted by $\mathrm{N} 2$ ( inconsistent with the usual status of N1 as phrasal head (cf. English forearm, which is not an arm, but part of an arm):

(6) a. naa5 phaak5 'forehead' (lit. 'forehead face')

b. khè̀n3 sò̀k5 'elbow' (lit. 'elbow arm')

c. khaa3 tooj4 'thigh' (lit. 'thigh leg')

d. khaa3 phapl 'back of knee' (lit. 'fold(ing) leg')

e. kon4 khii5 'anus' (lit. 'shit(ting) arse')

f. taa3 dam3 'pupil' (lit. 'black eye'; cf. taa3 khiaw3 'blue eyes')

g. thòòng4 nòòj4 'lower belly' (lit. 'small belly')

While rare, this pattern is also attested in other areas of the nominal lexicon. For example, khaj1 dè̀ng3 'yolk' (lit. 'red egg'); khaj1 khaaw3 'egg white' (lit. 'white egg').

\section{3. 'Body part syntax': expressing possession in grammatical constructions}

Certain grammatical constructions involving reference to a person and some part of that person's body express a relationship of possession (Chappell and McGregor, 1995), without morphological expression of the possessive relationship. (Critically, this 'possession' relationship is between the body part and the PERSON, not the person's BODY.) One type of construction is formally like a transitive sentence (i.e. is of the form NP1 V NP2), where the verb predicates either an action or an experience involving a part of the body, NP1 is a person, and NP2 is the relevant body part. More specific instantiations are:

(7) Transitive frame (agent-V-theme)

NP1 $1_{\text {AGENT (PERSON) }}$ V NP2 $2_{\text {THEME (BODY PART) }}$

(8) phen1 mùùn taa3

3SG open.eye eye

'He opened (his) eyes'. 
(9) Transitive frame (experiencer-V-locus)

NP1 $1_{\text {EXPERIENCER (PERSON) }} \mathrm{V}$ NP2 $2_{\text {LOCUS (BODY PART) }}$

(10) phen1 khan2 khaa3

3SG itch leg

'He itches (in the) legs'.

(11) kuu3 cêp2 lang3

$1 \mathrm{sg}$ sore back

'I (am) sore (in the) back'. 'My back is sore'.

The construction as a whole entails a relation of possession of the body part by the grammatical subject. You can't be sore in someone else's back. You can't use the verb mùùn 'open (the eyes)' to describe someone opening someone else's eyes.

The experience-denoting construction exemplified in (10) and (11) is not a regular transitive construction. A verb phrase such as khan2 khaa3 'itch leg' (in which khaa3 'leg' is not an undergoer but a Locus of experience) can itself take an additional nominal complement describing the stimulus of the experience. This structure incorporates a body part into a multi-participant predication, with roles corresponding to experiencer, locus of experience, and stimulus, in that order.

\section{phen1 khan2 khaa3 phaa5 hom1 maj1 3sG itch leg blanket new 'He itches (in the) legs (from his) new blanket'.}

A second type of construction takes the following form:

\section{(13) NP1 $1_{\text {THEME (HUMAN) }}$ NP2 BOdy PART $_{\text {ADJECTIVE }}$}

This is akin to a topic-comment construction ( $\mathrm{Li}$ and Thompson, 1976), in which a noun phrase in initial position is followed by what looks like a full clause with its own nominal subject and adjectival predicate. In the following example, kuu3 ' $\mathrm{I}$ ' is in initial position as the topic or 'setting' for the assertion phom3 dam3 '(the) hair (is) black':

(14) kuu3 phom3 dam3

1SG hair black

'I am black-haired'. (lit. 'I, [the] hair [is] black'.)

Here is another example:

(15) luuk4 caw4 khaa3 ñaaw2

child 2sG leg long

'Your child is long-legged'. (lit. 'Your child, [the] legs [are] long'.)

This looks like a topic-comment construction, and also like a nominal predicate construction. It differs from a typical topic-comment construction in that the sequence ' $\mathrm{NP}_{\text {BODY PART }} \mathrm{V}$ ' functions as a predicate in itself, directly taking verbal marking: 
(16)

luuk4 caw4 bòø khaa3 ñaw2
child 2sG NEG leg long
'Your child isn't long-legged'.

Superficially similar constructions cannot do this:

(17)
(a) ton4 sak2 baj3 ñaj1
tree teak leaf big
'The teak tree (has) big leaves'.
(b) *ton4 sak2 bòø baj3 nòoj4
tree teak NEG leaf small
(The teak tree (does) not (have) small leaves.)
(c) ton4 sak2 baj3 bòø nòoj4
'The teak tree (does) not (have) small leaves'.

\section{Semantic observations}

\subsection{Semantic content of body part terms}

Terms for parts of the body encode a range of different types of information (see introduction to this volume, Enfield, N.J., Majid, A., van Staden, M.). Previous authors such as Brown (1976) and Andersen (1978) among others, have stressed a perceptual basis for body part distinctions. As they have suggested, it is possible that the apparently significant cross-linguistic convergence of the meaning of many body part terms is due to a natural convergence on salient perceptible distinctions. These perceptible distinctions are also coupled with functional information, i.e. not only how a part of the body may be distinguished on the basis of how it looks and feels, but also by the actions and postures its structure affords its owner (e.g. legs being for walking, ears being for hearing) or an onlooker (e.g. face being for seeing what someone is thinking and/or feeling). It may be difficult to establish whether such specifications are encoded semantically or are simply part of one's knowledge about those parts. It is hard to imagine knowing the word leg and not knowing that one's legs figure centrally in walking. ${ }^{9}$

There are examples in Lao of explicit reference to function in the morphology of a complex expression. These include khaa3 phapl 'back of the knee' (literally 'fold(ing) leg', i.e. the '(part of) leg for folding') and kon4 khii5 'anus' (literally 'shit(ing) arse', i.e. the '(part of) arse for shitting').

At least one Lao term-khuan3 'spirit'-includes ONLY information about 'function', lacking any perception-based component whatsoever. Lao native speakers are clear about where it may be located (e.g. on top of the head, at the coil of the hair follicles), and can

\footnotetext{
${ }^{9}$ Relevant to this question are the range of idiomatic references to body parts which pick out precisely these functional components of meaning. For example, I nearly potted the black but it didn't quite have the legs picks out the 'for transport' component of legs; He has eyes in the back of his head picks out the 'for seeing' component of eyes; He gave me a hand picks out the 'for doing' component of hand; I saw the disappointment in his face picks out the 'revealing of internal state' component of face.
} 
say many things about its nature and function. But no perceptual image of the khuan3 can be derived from visual or proprioceptive experience (and while anyone may have a mental image of it, this image is not made accessible publicly, and therefore cannot be part of the conventional word meaning - $\mathrm{cf}$. the Punjabi term $k o D D i$ 'organ in the chest cavity deemed to be responsible for sickness' (Majid, this volume).

\subsection{Semantic relations among body part terms}

Each term listed in Tables 1-3 is a 'part of the body', as determined by the frame (1). However, relations below that level-i.e. AMONG the body part terms - are many and varied. There is no neat unifying set of semantic interrelationships among all the terms (as argued, for example, by Swanson and Witkowski, 1977, p. 324; pace Brown, 1976; Andersen, 1978). Instead, as discussed in the introduction to this issue, and as has come up occasionally in above sections, there are various types of semantic relation, including part-whole, possession, attachment, location, and general association (cf. McClure, 1975). This section provides examples of these in Lao, and illustrates their formal manifestation.

The part/whole relationship applies in a number of the Lao cases. For example, both khèèngl 'lower leg' and kok2 khaa3 'thigh' (lit. 'leg base') are truly parts of khaa3 'leg'. The evidence for this is firstly that the relationships may be expressed using the frame in (1), above. For example: (18) khè̀ngl pên3 suanl nùngl khòòng3 khaa3
lower leg is part one of leg

'The lower leg is a part of the leg'.

A second piece of evidence is an entailment test, as follows. If I cut a man's khè̀ngl 'lower leg', it entails that I have cut his khaa3 'leg'. Both of these tests provide evidence that tiin3 'foot' is NOT 'part of' khaa3 'leg'.

Expression of the relationship of possession in Lao is possible using a main verb mii 2 'have':

\section{kuu3 mii2 lot1 ñaj1/taa3 khiaw3/qaaj4}

1sG have car big/eye green/older_brother

'I have a big car/green eyes/an older brother'.

or a possessive noun phrase construction:
lot1 ñaj1/taa3 khiaw3/qaaj4
khò̀ng3 kuu3
car big/eye green/older_brother of $1 \mathrm{SG}$
'my big car/green eyes/older brother'

Body part terms described in this paper may all fit into both of these constructions, as long as the possessor in question is a PERSON, not a person's BODY (Swanson and Witkowski, 1977).

For relationships between parts of the body, it is odd in Lao to use either of the possessive constructions in (19) and (20). The relations between 'hand' and 'arm', or between 'face' and 'eye' are not ones of possession, as demonstrated by the oddity of the following examples: 
(21) (a) ?khèen3 mii2 mùù2

arm have hand

(The/an arm has a hand.)

(b) ?naa5 mii2 taa3

face have eye

(The/a face has eyes.)

(22)
(a) *mùù2 khòòng3 khèèn
hand of arm
(the hand of the arm)
(b) *taa3 khòong3 naa5
eye of face
(the eye(s) of the face)

The relation of physical attachment or connection is commonly expressed in Lao by means of a verb tò̀l 'attach, connect' in combination with the relational particle kap2 'with', in an expression meaning 'connecting to', 'joined to', 'continuing from'. This expression is appropriate for describing the relation between 'hand' and 'arm', but not that between 'nose' and 'face':
(a) mùù2 tòò kap2 khèèn3
hand connect with arm
'The hand is connected to the arm'.
(b) *dang3 tò̀1 kap2 naa5
nose connect with face
(the nose is connected to the face)

The nose/face relation is felicitously described in terms of LOCATION (cf. Palmer and Nicodemus, 1985), as is the hand/arm relation:
(a) dang3 juul kaang3 naa5
nose at centre face
(the nose is in the middle of the face)
(b) mùù juul paaj3 khè̀n3
hand at end arm
(the hand is at the end of the arm)

It is possible that most if not all relations between body parts are expressible in terms of location. Consider the relations mùù 'hand'/khèen3 'arm' and tiin3 'foot'/khaa3 'leg'. One hypothesis is that mùù 'hand' and tiin3 'foot' are PARTs of khèen3 'arm' and khaa3 'leg', respectively. A second is that mùù2 'hand' and tiin3 'foot' are ATTACHED To khèen3 'arm' and khaa3 'leg', respectively. A third possibility - the correct one, I argue - is that the relation is one of location. While either relation of possession or attachment is AVAILABLE AS AN INTERPRETATION of the hand/arm foot/leg relation, neither is semantically or otherwise inherently specified. Both possession and attachment are COMPATIBLE with the location relationship, but they are not entailed by it. A similar argument was made above with respect to the relation of ASSOCIATION, likely to be the only relation general enough to cover the range of semantic relations encoded by the N1-N2 compounds found in complex body part terminology. 
In this section I have pointed out several types of semantic relationship that pertain between Lao terms for parts of the body, along with ways of identifying and expressing them. It is beyond the scope of the present context to establish the full set of relationships between all the body part terms, but I have provided an outline of the kinds of structures available for doing this in Lao. The main point of this section has been to draw attention to the fact that under the hood of this putative partonomy lies a textured and heterogeneous semantic domain.

\section{Conclusion}

The inventory of Lao terms for parts of the body described in this article represents one actual solution to a community's collective and historical problem of establishing public conventions for conceptual coordination within a complex phenomenological domain. Many Lao terms have meanings which are similar, if not identical, to those observed in other languages such as English. Some terms are less familiar from a non-Lao perspective. This is true especially where culture-related connotations come into play, such as in the avoidance in Lao of explicit reference to the feet. The Lao data demonstrate that the lexical domain of body partonomy, while unified by its definition with reference to the human body, shows considerable variation in internal structure. The semantic relations which pertain between terms for different parts of the body not only include part/whole relations, but also relations of location, connectedness, and general association. Calling the whole system a 'partonomy' attributes greater centrality to the part/whole relation than is warranted.

\section{Acknowledgements}

Many thanks to my consultants Pitsana, Kou, Loy, Xai, Sai, and Thong. I am grateful to the Max Planck Society for its support of this research. I am also grateful to Niclas Burenhult, Steve Levinson, Asifa Majid, Miriam van Staden, and two anonymous reviewers for comments.

\section{Appendix}

There is no standard Romanisation of Lao. Examples are transcribed according to the following conventions:

\begin{tabular}{|c|c|c|c|c|c|c|c|c|}
\hline \multicolumn{5}{|c|}{ Consonants } & \multicolumn{3}{|c|}{ Vowels } & \multirow{2}{*}{$\begin{array}{l}\text { Tones } \\
\text { 1. Mid level }\end{array}$} \\
\hline$b$ & $d$ & & & & $i$ & & $u$ & \\
\hline$p$ & $t$ & $c$ & $k$ & $q$ (glottal stop) & & & $\grave{u}$ (unrounded) & 2. High rising \\
\hline$p h$ & th & & $k h$ & & $\hat{e}$ & $e$ & $o$ & 3. Low rising \\
\hline$m$ & $n$ & $\tilde{n}$ & $n g$ & & & & & 4. High falling \\
\hline$f$ & $s$ & & $h$ & & $\grave{e}$ & $a$ & $\grave{o}$ & 5. Low falling \\
\hline$w$ & $l$ & $j$ & & & & & & ø. Unstressed \\
\hline
\end{tabular}




\section{References}

Aikhenvald, Alexandra Y., 2000. Classifiers. Oxford University Press, Oxford.

Andersen, E.S., 1978. Lexical universals of body-part terminology. In: Greenberg, J.H. (Ed.), Universals of Human Language, Word Structure, vol. 3. Stanford University Press, Stanford, pp. 335-368.

Brown, C.H., 1976. General principles of human anatomical partonomy and speculations on the growth of partonomic nomenclature. American Ethnologist 3, 400-424.

Chafe, W., 2000. Loci of diversity and convergence in thought and language. In: Pütz, M., Verspoor, M. (Eds.), Explorations in Linguistic Relativity. Benjamins, Amsterdam, pp. 101-123.

Chappell, H., McGregor, W. (Eds.), 1995. The Grammar of Inalienability. Mouton de Gruyter, Berlin.

Diller, A.V.N., Juntanamalaga, P., 1990. Full hearts and empty pronominals in Thai. Australian Journal of Linguistics 19, 231-256.

Enfield, N.J., 2001. Linguistic evidence for a Lao perspective on facial expression of emotion. In: Harkins, J., Wierzbicka, A. (Eds.), Cross-cultural Semantics of Emotion. Mouton de Gruyter, Berlin, pp. 153-170.

Enfield, N.J., 2002. Semantic analysis of body parts in emotion terminology: avoiding the exoticisms of 'obstinate monosemy' and 'online extension'. Pragmatics and Cognition 10, 81-102.

Enfield, N.J., 2004a. Nominal classification in Lao: a sketch. In: Aikhenvald, A.Y. (Ed.), Sprachtypologie Und Universalienforschung 2/3, 2004. Special Issue on Classifiers, pp. 117-143.

Enfield, N.J., 2004b. Adjectives in Lao. In: Dixon, R.M.W., Aikhenvald, A.Y. (Eds.), Adjective Classes: a CrossLinguistic Typology. Oxford University Press, Oxford, pp. 323-347.

Enfield, N.J., this volume. Elicitation guide on parts of the body. In: Majid, A., Enfield, N.J., van Staden, M. (Eds.), Parts of the body: Cross-Linguistic Categorisation (Special Issue). Language Sciences, doi:10.1016/ j.langsci.2005.11.003.

Enfield, N.J., Majid, A., van Staden, M., this volume. Cross-linguistic categorisation of the body: introduction. In: Majid, A., Enfield, N.J., van Staden, M., Parts of the Body: Cross-Linguistic Categorisation (Special Issue). Language Sciences, doi:10.1016/j.langsci.2005.11.001.

Grinevald, C., 2000. A morphosyntactic typology of classifiers. In: Senft, G. (Ed.), Systems of Nominal Classification. Cambridge University Press, Cambridge, pp. 50-92.

Juntanamalaga, P., 1992. On the semantics of Thai compounds in Hua 'Head'. In: Compton, C.J., Hartmann, J.F. (Eds.), Papers in Tai Languages, Linguistics, and Literatures. Northern Illinois University, Center for Southeast Asian Studies, DeKalb, pp. 168-178.

Langacker, R.W., 1987. Foundations of Cognitive Grammar. Stanford University Press, Stanford.

Li, C.N., Thompson, S.A., 1976. Subject and topic: a new typology of language. In: Li, C.N. (Ed.), Subject and Topic. Academic Press, New York, pp. 457-489.

Majid, A., this volume. Body part categorisation in Punjabi. In: Majid, A., Enfield, N.J., van Staden, M. (Eds.), Parts of the Body: Cross-Linguistic Categorisation (Special Issue). Language Sciences, doi:10.1016/ j.langsci.2005.11.012.

Matisoff, J.A., 1986. Hearts and minds in southeast Asian languages and English: an essay in the comparative lexical semantics of psycho-collocations. Cahiers De Linguistique Asie Orientale 15, 5-57.

McClure, E.F., 1975. Ethno-anatomy: the structure of the domain. Anthropological Linguistics 17, 78-88.

Palmer, G.B., Nicodemus, L., 1985. Coeur d'Alene exceptions to proposed universals of anatomical nomenclature. American Ethnologist 12, 341-359.

Schaefer, R.P., 1985. Toward universal semantic categories for human body space. Linguistics 23, 391-410.

Swanson, R.A., Witkowski, S., 1977. Hopi ethnoanatomy: a comparative treatment. Proceedings of the American Philosophical Society 121, 320-337.

Wierzbicka, A., 1980. Lingua Mentalis. Academic Press, Sydney.

Wierzbicka, A., 1996. Semantics: Primes and Universals. Oxford University Press, Oxford. 